\title{
The Antibacterial Activity Screening of the Extracts of Some Moroccan Medicinal Plants
}

\author{
Youssef LAHLOU, Belkassem EI AMRAOUI, Toufiq BAMHAOUD
}

\begin{abstract}
The antibacterial and antifungal activities of some Moroccan medicinal plants extracts were evaluated against six bacterial species and three yeasts.

The agar diffusion method was used to evaluate the antimicrobial activity of the extracts of the following medicinal plants: Rosmarinus officinalis, Salvia officinalis, Psidium guajava, Crocus sativus, Dysphania ambrosioides, Trigonella foenum graecum and Cymbopogon citratus. The used standard antibiotic is the

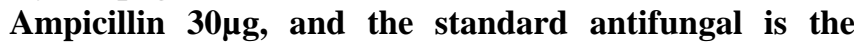
Econazole30 $\mu$ g.

The highest antibacterial activity was observed for the extracts of Rosmarinus offficinalis $(16,6 \mathrm{~mm}<\mathrm{d}<26 \mathrm{~mm})$ and Salvia offficinalis $(18 \mathrm{~mm}<\mathrm{d}<22 \mathrm{~mm})$, which are very close to that of some standard antibiotic (ampicilline $30 \mu \mathrm{g}$ ) who recorded zones of inhibition from 24 to $29 \mathrm{~mm}$. In the second class there is Psidium guajava extracts, with a moderate antibacterial activity $(9 \mathrm{~mm}<\mathrm{d}<12 \mathrm{~mm})$ against Pseudomonas.sp, Staphylococcus aureus, Enterococcus faecalis and Escherichia. coli. The extract of Crocus sativus, Trigonella foenum graecum and Cymbopogon citratus showed a low antibacterial activity $((\mathbf{8 m m}<\mathrm{d}<9 \mathrm{~mm})$, against four bacterial strains among five tested. No antimicrobial activity was obtained for Dysphania ambrosioides extracts .

This study proves, in part, that excepted Dysphania ambrosioides all the studied medicinal plants extracts have a good antibacterial activity, so they can establish a source of alternative antibiotics in the pharmaceutical industry. On the other hand, the species of these studied medicinal plants could be valuable due to their bioactive compounds. The results confirm also the ethnobotanical importance of the screened plants for the treatment of some bacterial infections.
\end{abstract}

Index Terms- Rosmarinus officinalis, Salvia officinalis, Stapylococcus aureus, antibacterial activity, antifongal activity

\section{INTRODUCTION}

Since Antiquity, the humanity used diverse resources of the environment to handle the diseases [1]. At present, medicine with plants is widely used[2]. Consequently, more than 120

Youssef LAHLOU, Laboratory of Biotechnology, Biochemistry \& Nutrition. Control Quality in Bio-control Industry \& Bioactive Molecules research team. Faculty of Sciences El Jadida, Morocco

Belkassem El AMRAOUI, Biotechnology, Materials and Environment Laboratory, Faculty Polydisciplinary of Taroudant, Ibn Zohr University, Agadir, Morocco

Toufiq BAMHAOUD, Laboratory of Biotechnology, Biochemistry \& Nutrition. Control Quality in Bio-control Industry \& Bioactive Molecules research team. Faculty of Sciences El Jadida, Morocco compounds resulting from plants are used in modern medicine [3]. Also 5 in $15 \%$ of vegetables inventoried in the world were the object of current researches on bioactive molecules, representing an immense reservoir of new potential medicinal compounds [4-6]. The use of antibiotics of synthesis and mainly the resistance of the pathogenic microorganisms became a public health problem in the world $[7,8]$. It is important to find new molecules having an antibacterial activity. Many aromatic and medicinal plants which have antimicrobial properties are known for several centuries [9]. It's in this context that our study was realized with an objective to evaluate the antimicrobial activity of some medicinal Moroccan's plants. Therefore, the extracts of seven medicinals plants (Rosamarinus officinalis, Salvia officinalis, Psidium guajava, Crocus sativus , Dysphania ambrosioides, Trigonella foenum graecum and Cymbopogon citratus), from different families were tested for their potential activity against bacteria.

\section{MATERIALS AND METHODS}

\section{A. Medicinal plants:}

The studied medicinal plants were collected in the region of El Jadida and one plant of the region of Taliounine (Crocus sativus ), that is known in Morocco and in the world by the crop of a good quality of Saffron. This cultivated plants are free of pesticides. Medicinal plants, place of harvest and the part used in this study were grouped in the table I.

\section{A. Preparation of the extract}

After their collection, the fresh plant material was dried in the oven under a temperature of $50{ }^{\circ} \mathrm{C}$ to obtain the dry matter, which is grounded in the electric grinder Moulinex-type to obtain the dry powder. The dried and powdered plant materials $(100 \mathrm{~g})$ was macerated for 48 hours at room temperature in a mixture of two solvents, a polar solvent (Ethanol) and a non-polar solvent (Dichloromethane) with a proportion of 50\%:50\%. The mixture was after that filterd using Whatman filter paper then the filtrat was concentrated in vacuo at $40{ }^{\circ} \mathrm{C}$ using a Rotary evaporator until the total elimination of the solvent and the dried crude extract is obtained. The crude extracts of every plants were stored in a freezer at $4{ }^{\circ} \mathrm{C}$ until further tests. 
The Antibacterial Activity Screening of the Extracts of Some Moroccan Medicinal Plants

Table I: Name; parts and harvesting site of studied medicinal plants

\begin{tabular}{|l|l|l|l|c|}
\hline Scientific name & Common name & Family & The used part & Harvesting site \\
\hline Psidium guajava & Guava & Mytraceae & Leaves, fruits & El Jadida \\
\hline Cymbopogon citratus & Lemongrass & Poaceae & Leaves & El Jadida \\
\hline Dysphania ambrosioides & Epazote & Chenopodiaceae & Leaves & El Jadida \\
\hline $\begin{array}{l}\text { Trigonella } \\
\text { foenum-graecum }\end{array}$ & Fenugreek & Fabaceae & Leaves & El Jadida \\
\hline $\begin{array}{l}\text { Salvia officinalis } \\
\text { Crocus sativus }\end{array}$ & Sage & Lamiaceae & Leaves & Taliouine \\
\hline Rosmarinus officinalis & Saffron crocus & Iridaceae & Leaves & El Jadida \\
\hline
\end{tabular}

\section{B. Test microorganisms}

Five bacteria species obtained from the Institute Pasteur of Paris Collection ( CIP) and from an American Type Culture Collection ( ATCC) were used as antimicrobial strains: Citrobacter freundii ATCC8090, Escherishia coli CIP54127, Pseudomonas sp, Enteroccus faecalis ATCC19433, Staphlococcus aureus CIP 209 (ATCC 25923), Candida tropicalis R2 CIP1275.81, Candida albicans 48.72 and Cryptococcus neoformans CIP960. The bacterial strains were maintained on the Mueller-Hinton agar medium.

The choice of these bacteria is explained by their availability in our laboratory and by the high pathogenic power of these bacteria, since they are at the origin of several infections and diseases in humans, fish in aquaculture or in other animals such as chicken such as urinary tract, respiratory tract, meningitis and other infections [10-24].

\section{Antibacterial assay}

The antibacterial activity of the crude plant extracts was studied using the disc diffusion method [25]:

The inoculum of bacteria was prepared from colonies in phase of exponential growth from the culture from 18 to 24 hours old on the gelose of Mueller-Hinton ( $\mathrm{MH}$ ).

The cellular density was estimated by counting using a cell of Malassez, adjusted by dilution in sterile physiological water to obtain a final concentration of $106 \mathrm{UFC} / \mathrm{ml}$.
The disks of cellulose of $6 \mathrm{~mm}$ as diameter, were saturated by $20 \mu \mathrm{l}$ of extract solution to $25 \mathrm{mg} / \mathrm{ml}$ of solvent $(25 \mathrm{mg}$ of the extract dissolved in one $\mathrm{ml}$ of solvent), $500 \mu \mathrm{g}$ of extract by disk. After drying at room temperature, the disks were deposited on Petri dishes containing the test culture medium already sowed with a target germ (MHA to $106 \mathrm{UFC} / \mathrm{ml}$ ). After two hours in $4^{\circ} \mathrm{C}$, the Petri dishes were incubated in 37 ${ }^{\circ} \mathrm{C}$ during 24 at 72 hours.

The evaluation of the antibacterial and antifungal activity of every extracts were validated by the measure of the diameters of the zones of inhibition appearing around the disks, in comparison with the standard antibiotics (ampicilline $30 \mu \mathrm{g}$ ). Every test was realized in triplicate.

\section{RESULTS AND DISCUSSION}

\section{A. RESULTS}

- Antibacterial activity of the medicinal plants extracts against the tested bacteria

The results obtained in the antibacterial assay are shown in Table II. As it can be seen, excepted the leaf extract of Dysphania ambrosioides that showed no antimicrobial activity, all the extracts showed varying degrees of antibacterial activity against the Gram-positive and Gram-negative bacteria tested, with zone of inhibition ranging from $9 \mathrm{~mm}$ to $26 \mathrm{~mm}$.

The screening of the antibacterial activity of the studied medicinal plants extract are presented in the table II.

Table II: In vitro screening of antibacterial activity of the medicinal plants extracts

\begin{tabular}{|l|l|l|l|l|l|}
\hline \multirow{2}{*}{ The crude extracts } & \multicolumn{4}{|l|}{ Diameters of the zones of inhibition $\mathbf{( m m )}$} & \multicolumn{2}{l|}{ Gram-positive bacteria } \\
\cline { 2 - 6 } & \multicolumn{2}{|l|}{ Gram-negative bacteria } & $\begin{array}{l}\text { Citrobacter } \\
\text { freundii }\end{array}$ & $\begin{array}{l}\text { Enterococcus } \\
\text { faecalis }\end{array}$ & $\begin{array}{l}\text { Staphylococcus } \\
\text { aureus }\end{array}$ \\
\cline { 2 - 6 } & Escherichia. coli & Pseudomonas sp & $22 \pm 2,00$ & 21,73 \\
\hline Salvia officinalis & $18 \pm 1,73$ & $20 \pm 2,65$ & $20 \pm 3,00$ & $21 \pm 2,08$ & $19 \pm 2,15$ \\
\hline $\begin{array}{l}\text { Rosmarinus } \\
\text { officinalis }\end{array}$ & $16,6 \pm 1,15$ & $26 \pm 1,03$ & $19,6 \pm 2,07$ & $11 \pm 2,65$ \\
\hline $\begin{array}{l}\text { Psidium guajava } \\
\text { (leaves) }\end{array}$ & $8 \pm 1,00$ & $11 \pm 2,00$ & $8 \pm 1,00$ & $11 \pm 1,73$ & \\
\hline $\begin{array}{l}\text { Trigonella foenum } \\
\text { graecum }\end{array}$ & $9 \pm 1,00$ & $9 \pm 1,73$ & - & $8 \pm 0,00$ & $8 \pm 1,00$ \\
\hline
\end{tabular}




\begin{tabular}{|l|l|l|l|l|l|} 
Crocus sativus & $9 \pm 2,00$ & $9 \pm 0,00$ & - & $8 \pm 2,00$ & $8 \pm 0,00$ \\
\hline $\begin{array}{l}\text { Psidium guajava } \\
\text { fruits) }\end{array}$ & $9 \pm 1,73$ & $12 \pm 0,58$ & - & $9 \pm 2,00$ & $8 \pm 0,00$ \\
\hline $\begin{array}{l}\text { Cymbopogon } \\
\text { citratus }\end{array}$ & $8 \pm 1,73$ & $9 \pm 1,00$ & - & $9 \pm 0,00$ & - \\
\hline $\begin{array}{l}\text { Dysphania } \\
\text { ambroisies }\end{array}$ & - & - & - & - & - \\
\hline Ampicilline $30 \mu \mathrm{g}$ & 27 & 25 & 25 & 29 & 24 \\
\hline
\end{tabular}

The extracts of Salvia officinalis and Rosmarinus officinalis showed an excellent antibacterial activity against all the germs bacterial tested, are presented by their zones of inhibition between $18 \mathrm{~mm}$ and $22 \mathrm{~mm}$ against Escherishia coli and Enterococcus faecalis respectively. The Rosmarinus officinalis extract showed a zone of inhibition between 16,6 $\mathrm{mm}$ and $26 \mathrm{~mm}$, against Escherishia coli and Pseudomonas $s p$ respectively, the values are very close to the standard antibiotic used (ampicilline30 $\mu \mathrm{g}$ ) which registered the zones of inhibition between 24 to $29 \mathrm{~mm}$ (Fig 1). With stronger antibacterial action of Salvia officinalis extract against Gram+ bacteria $(\mathrm{d}=21,5 \mathrm{~mm})$ compared to Gram- bacteria $(\mathrm{d}=19,33 \mathrm{~mm})$ which are therefore a little resistant to this extract, contrary to Rosmarinus officinalis extract, where the Gram- $(d=20,73 \mathrm{~mm})$ bacteria are the most sensitive, the Gram+ bacteria are somewhat resistant $(\mathrm{d}=19 \mathrm{~mm})$.

The extract of Psidium guajava (leaves and fruits) was able to inhibit four bacterial strains among five tested, with a moderate antibacterial activity against Pseudomonas. sp $(\mathrm{d}=12 \mathrm{~mm})$, Enterococcus faecalis and Staphylococcus aureus $(\mathrm{d}=11 \mathrm{~mm})$, a low antibacterial activity against Escherichia coli $(\mathrm{d}=9 \mathrm{~mm})$ and a none antibacterial activity against Citrobacter freundii.

The extracts of Crocus sativus and Trigonella foenum-graecum shows a low activity, presented by a zones of inhibition of $9 \mathrm{~mm}$, against all of the tested bacteria with the exception of Citrobacter freundii who present no antibacterial activity, followed by the extract of Cymbopogon citratus with a low antibacterial activity only against Escherishia coli, Pseudomonas sp and Entercoccus faecalis. Finaly, The leaf extract of Dysphania ambrosioides did not show any antibacterial activity against any tested bacterium.

- Sensitivity of bacteria to the studied medicinal plant extracts according to their Gram

The sensitivity of bacteria to the studied medicinal plant extracts according to their Gram shows that Gram- bacteria are more resistant than Gram+ bacteria which are more sensitive to the most of studied medicinal plant extracts. Indeed for the extract of Salvia officinalis, Psidium guajava, Trigonella foenum-graecum and Crocus sativus, Gram-bacteria are more resistant than Gram+ bacteria. However, for the extract of Rosmarinus officinalis and Cymbopogon citratus, Gram+ bacteria are more resistant than Gram-bacteria (Fig1).

more resistant than Gram-bacteria (Fig1).

\section{B. DISCUSSION}

Firstly, the antibacterial activity schowed that the leaf extracts of Rosmarinus officinalis and Salvia officinalis have a strong antibacterial activity against all the tested bacteria (Fig.1).
As regarding to Salvia officinalis extract, these findings are in accordance with the results recorded in the investigation of many publications have documented the antibacterial activity of S.officinalis extracts against different bacterial species[26-34]. . The aqueous extract of S. officinalis has already shown antibacterial activity against Bacillus mycoides, Bacillus subtilis, Enterobacter cloacae, Escherichia coli, and Proteus sp [35]. Similarly, The supercritical fluid sage extracts revealed excellent growth inhibition against Escherichia coli, Pseudomonas aeruginosa, Bacillus subtilis, and Staphylococcus aureus[36],the hydroalcoholic extract is actif against $S$. aureus, and Klebsiella oxytoca [37] and the ethanolic extract has already shown a strong bactericidal and bacteriostatic effects against both Gram-positive and Gram-negative bacteria [38]. This antibacterial activity of S.officinalis extracts is positively related to their phenolic composition [39] such as terpens and terpenoids compounds found in this plant[38] or their oleanolic acid, ursolic acids and their Carnosol and carnosic acid [36,40-42]. As reported rosmanol and ferruginol are also responsible for the biological activity of sage along with the phenolic rosmarinic and salvianolic acids [43]. But, the antibacterial activity of S.officinalis extracts can also be due to the presence of interaction between different volatile constituents [44].

About Rosmarinus officinalis known for these medicinal virtues around the world [45], according to the results obtained in the present work, Genena and al in 2008 was mentioned that $R$. officinalis leaf extracts obtained by SFE extraction a good antibacterial activity against Gram+ bacteria (Staphylococcus aureus and Bacillus cereus) and Gram- bacteria (Escherichia coli) [46], two years later, other studies mentioned that the extract of $R$. officinalis has antibacterial activity against clinical Methicillin-resistant Staphylococcus aureus and against Listeria species such as Listeria grayi, Listeria innocua, Listeria ivanovii and Listeria monocytogene [47-49]. In 2012, Rosemary leaf extracts showed a stronger antimicrobial activity against Bacillus cereus, C. jejuni, S.infantis [50]. Similar finding was proposed recently in 2015 against S. epidermidis, $B$. bronchiseptica, G. stearothermophilis [51], against Enterococcus faecalis, Streptococcus mutans and [52], in 2017 against E. coli and S. aureus bacteria [53] and in 2018 against $S$. aureus, S. epidermidis, $P$. aeruginosa, B. cereus [54]. This antibacterial activity of rosemary against all the the tested bacteria could be attributed to the presence of flavonoids, phenolic acids (caffeic, chlorogenic, carnosic and rosmarinic) $[49,55,56]$ and other apolar phenolic compounds [57,58]. Moreever, carnosic acid is more efficient against gram-positive bacteria than rosmarinic acid [59], since, carnosic acid was the major bioactive compound of the 
rosemary extract but its derivative and other compounds like carnosol, rosmarinic acid, etc. have also important antimicrobial activity[47].

There is also some evidence that minor components have a critical part in antibacterial activity, possibly by producing a synergistic effect between other components [54,60].

Secondary. Regarding the extracts of Psidium guajava, it should be noted that this is the first study on the antibacterial activity of this newly introduced species in Morocco, since it is native to South America, So the results of this study are very interesting. The result indicate that in spite of the lower antibacterial activity of Psidium guajava extracts (leaves extract and fruits extract), it remains considerable with a zone of inhibition between 8 en $12 \mathrm{~mm}$. These results are very close to those found by Biswas in 2013, when the ethanol extract showed a zone of inhibition of 6.11 and $11 \mathrm{~mm}$ against Staphylococcus aureus and Bacillus cereus, respectively [61]. Indeed, several other studies confirm the antibacterial effect of Psidium guajava [62], the methanol and ethanol extracts showed inhibitory activity against the gram-negative bacteria known by the resistance such as Acinetobacter baumannii, Proteus mirabilis, Salmonella sp, Shigella flexneri, E.coli, Pseudomonas Sp [61,63-65], but also against Gram+ bacteria like Staphylococcus aureus, Staphylococcus haemolyticus, Staphylococcus epidermdidis $[65,66]$, and caused by the impermeability of the bacteria to any lipopolysaccharide membrane in the presence of active component of Psidium guajava that are the tannins that have an effect of limiting the multiplication of Staphylococcus aureus by inhibition phosphorylation activity of bacteria forming its cell wall which can cause multiplication of bacteria[66]. This antibacterial activity possibly due to protein degrading activity of the extract[67], can be associated with the existence of some bioactive ingredients such as; Saponins, Flavonoids, Tannins, Alkaloids, Phenols, and Phyto Sterols in both plants effective against several strains of pathogenic bacteria $[64,68]$.

As regards the extract of Crocus sativus, Trigonella foenum graecum citratus, which showed an average antibacterial activity with a diameter of inhibition zone between 8 and $9 \mathrm{~mm}$ against all the tested bacteria excepted Citrobacter freundii, which is therefore considered a resistant bacteria. Indeed, the results of Trigonella foenum-graecum leaves extract are in accordance with the previous studies which stipulate that the leaves methanol extract has an antibacterial activity against Escherichia coli $(20 \mathrm{~mm})$, Pseudomonas aeruginosa (9,2mm) [69] and against Staphylococcus aureus [70], and more than the result observed by Sharma et al for the aqueous extract [71]. This antibacterial activity is due to the fact that the leaves of Trigonella foenum-graecum are rich in a wide variety of secondary metabolites such as glycosides, alkaloids, phytosterols, proteins, saponins and phytosterols which have been found in vitro to have antimicrobial properties [69]. The results of Crocus sativus are very similar to those found by Muzaffar in 2016, of the extracts of Crocus sativus against Proteus vulgaris, Klebsiella pneumoniae, Pseudomonas aeruginosa, Staphylococcus aureus and Escherishia coli, with a zone of inhibition of $8 \mathrm{~mm}, 6 \mathrm{~mm}, 9 \mathrm{~mm}, 7 \mathrm{~mm}$, and $6 \mathrm{~mm}$, respectively [72], and also by Okmen in 2016, when aqueous extract of Crocus sativus showed a maximum inhibition zone against Coagulase- Negative Staphylococci $(\mathrm{d}=11 \mathrm{~mm})[73]$

The antibacterial activity of Cymbopogon citratus extract is somewhat lower, since it is active only against three bacteria (Escherichia coli, Pseudomonas sp, Enterococcus faecalis) and inactive against Citrobacter freundii and Staphylococcus aureus. Bearing, These results remain interesting, since the diameters of the inhibition zones obtained are very close to the other studies, Zulfa et al in 2016, found that Cymbopogon citratus extracts has an antimicrobial activity against the foodborne pathogens; Bacillus cereus, Escherishia coli, K.pneumonia, and Staphylococcus aureus [74], Moreover, Ewansiha and all also confirmed that the Cymbopogon citratus chloroform leaf extracts showed an intermediate antimicrobial activity against Staphylococcus aureus, Salmonella typhi and Escherishia coli[75]. This antibacterial activity can be attributed to the richness of the species in active components like alkaloids, tannis, flavanoids, terpenes and phenolic compounds [76,77], caused membrane disruption or affected the genetic materials of bacteria [78].

Finally, the leaf extracts of Dysphania ambrosioide did not show any antibacterial activity against targets bacterial studied, as it was already demonstrated for Dysphania ambrosioide collected from Meknés city (Morocco) with no antibacterial effect [79] in contrary to Brazilian[80] or Pakisani [81] Dysphania ambrosioide which showed good antibacterial activity. These difference can be related to the geographical localization and environmental factors connected, who are one of the major determinants of plant secondary metabolites $[82,83]$ responsible of the plant antimicrobial activity. Despite this, it should be noted that the absence of inhibition zone does not necessarily mean that compounds are inactive. For example, non-polar compounds may not diffuse into the culture medium [55].

In the other hand, the sensitivity of bacteria to the studied medicinal plant extracts according to their Gram, showed that Gram negative bacteria are more resistant compared to Gram positive bacteria. This finding are in agreement with previous data demonstrating greater activity of the plant extracts towards Gram+ bacteria compared to Gram-bacteria, which can be explained by the fact that Gram-bacteria are more resistant than Gram+ bacteria [51,84-94].

One of the most plausible reasons behind such observation, as also mentioned by others, is the different nature of cell wall among Gram+ and Gram- bacteria[92]. Morever, efflux pump system of Gram-bacteria may mediate for such difference, by the outer membrane surrounding the cell wall in gram-bacteria and the periplasmatic space containing enzymes which are capable of breaking down foreign molecules introduced from outside [95-98]. 

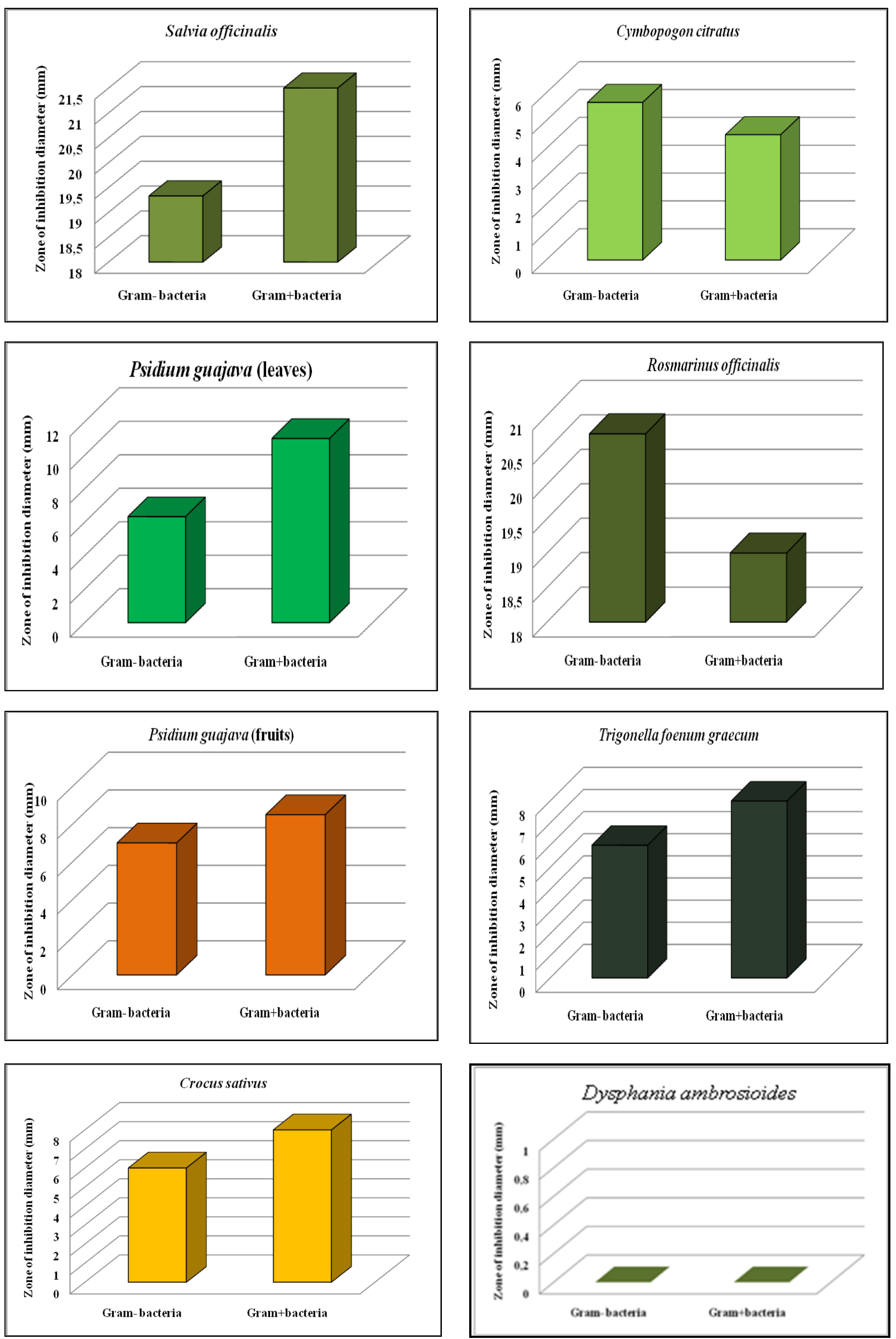

Fig.2: Sensitivity of bacteria to the studied medicinal plant extracts according to their Gram 


\section{CONCLUSION}

This study proves, in part, that excepted Dysphania ambrosioides all the studied medicinal plants extracts have a good antibacterial activity, so they can establish a source of alternative to antibiotics in the pharmaceutical industry, on the other hand, the species of the studied medicinal plants could be valuable due to their bioactive compounds.

\section{ACKNOWLEDGMENT}

We thank Mr Ali Sbai, manager of Environment Univers water and soil analysis laboratory for his technical assistance and professor BELAHSEN Rekia, director of Laboratory of Biotechnology, Biochemistry and Nutrition (LBBN) for his scientific and technical support.

\section{CONFLIT OF INTEREST}

The authors declare no conflict of interest.

\section{REFERENCES}

[1] K.-H. Lee. "Current developments in the discovery and design of new drug candidates from plant natural product leads," Journal of natural products. vol. 67, 2004, pp. 273-283.

[2] A. Abedini. Evaluation biologique et phytochimique des substances naturelles d'Hyptis atrorubens Poit.(Lamiaceae), sélectionnée par un criblage d'extraits de 42 plantes. In: Université du Droit et de la Santé-Lille II; 2013

[3] G.A. Cordell, M.D. Colvard. "Some thoughts on the future of ethnopharmacology," Journal of Ethnopharmacology. vol. 100, 2005, pp. 5-14.

[4] D.S. Fabricant, N.R. Farnsworth. "The value of plants used in traditional medicine for drug discovery," Environmental health perspectives. vol. 109, 2001, pp. 69.

[5] J. Larsson, J. Gottfries, L. Bohlin, A. Backlund. "Expanding the ChemGPS chemical space with natural products," Journal of natural products. vol. 68, 2005, pp. 985-991.

[6] H.G. Cutler, S.J. Cutler. Biologically active natural products: agrochemicals: CRC Press; 1999

[7] A. Abedini. Evaluation biologique et phytochimique des substances naturelles d'Hyptis atrorubens Poit.(Lamiaceae), sélectionnée par un criblage d'extraits de 42 plantes. In: Université du Droit et de la Santé-Lille II; 2013

[8] A.J. Alanis. "Resistance to antibiotics: are we in the post-antibiotic era?," Archives of medical research. vol. 36, 2005, pp. 697-705.

[9] Y. Yano, M. Satomi, H. Oikawa. "Antimicrobial effect of spices and herbs on Vibrio parahaemolyticus," International Journal of Food Microbiology. vol. 111, 2006, pp. 6-11.

[10] J.L. Badger, M.F. Stins, K.S. Kim. "Citrobacter freundii invades and replicates in human brain microvascular endothelial cells," Infection and immunity. vol. 67, 1999, pp. 4208-4215.

[11] K. Ranjan, N. Ranjan. "Citrobacter: an emerging health care associated urinary pathogen," Urology annals. vol. 5, 2013, pp. 313.

[12] L.-H. Liu, N.-Y. Wang, A.Y.-J. Wu, C.-C. Lin, C.-M. Lee, C.-P. Liu. "Citrobacter freundii bacteremia: risk factors of mortality and prevalence of resistance genes," Journal of Microbiology, Immunology and Infection. vol. 51, 2018, pp. 565-572.

[13] C.-C. Shih, Y.-C. Chen, S.-C. Chang, K.-T. Luh, W.-C. Hsieh. "Bacteremia due to Citrobacter species: significance of primary intraabdominal infection," Clinical Infectious Diseases. vol. 23, 1996, pp. 543-549.

[14] M. Koshy, R. Ralph, K.P.P. Abhilash, G.M. Varghese. "Citrobacter freundii: A rare cause of native valve endocarditis," Journal of Medical Society. vol. 30, 2016, pp. 182.

[15] I. Altinok, S. Kayis, E. Capkin. "Pseudomonas putida infection in rainbow trout," Aquaculture. vol. 261, 2006, pp. 850-855.

[16] S.T. Micek, A.E. Lloyd, D.J. Ritchie, R.M. Reichley, V.J. Fraser, M.H. Kollef. "Pseudomonas aeruginosa bloodstream infection: importance of appropriate initial antimicrobial treatment," Antimicrobial agents and chemotherapy. vol. 49, 2005, pp. 1306-1311.

[17] F. Vidal, J. Mensa, M. Almela, J.-A. Martínez, F. Marco, C. Casals, J.-M. Gatell, E. Soriano, M.-T.J. de Anta. "Epidemiology and outcome of Pseudomonas aeruginosa bacteremia, with special emphasis on the influence of antibiotic treatment: analysis of 189 episodes," Archives of Internal Medicine. vol. 156, 1996, pp. 2121-2126.

[18] F. Barbier, M. Wolff. "Multirésistance chez Pseudomonas aeruginosa-Vers l'impasse thérapeutique?," médecine/sciences. vol. 26, 2010, pp. 960-968.

[19] G.P. Bodey, R. Bolivar, V. Fainstein, L. Jadeja. "Infections caused by Pseudomonas aeruginosa," Reviews of infectious diseases. vol. 5, 1983, pp. 279-313.

[20] A.A. Wahab, M.M. Rahman. "Pseudomonas aeruginosa bacteremia secondary to acute right leg cellulitis: case of community-acquired infection," EXCLI journal. vol. 12, 2013, pp. 997.

[21] A. Alhazmi. Pseudomonas aeruginosa - Pathogenesis and Pathogenic Mechanisms; 2015

[22] J.L.L. Ferreiro, J.Á. Otero, L.G. González, L.N. Lamazares, A.A Blanco, J.R.B. Sanjurjo, I.R. Conde, M.F. Soneira, J. de la Fuente Aguado. "Pseudomonas aeruginosa urinary tract infections in hospitalized patients: Mortality and prognostic factors," PloS one. vol. 12, 2017, pp. e0178178.

[23] M.R. Pinheiro, H.R. Lacerda, R.G. Melo, M. Maciel. "Pseudomonas aeruginosa infections: factors relating to mortality with emphasis on resistance pattern and antimicrobial treatment," Brazilian Journal of Infectious Diseases. vol. 12, 2008, pp. 509-515.

[24] G. Rossolini, E. Mantengoli. "Treatment and control of severe infections caused by multiresistant Pseudomonas aeruginosa," Clinical microbiology and infection. vol. 11, 2005, pp. 17-32.

[25] F. Capasso, R. De Fusco, M. Fasulo, M. Lembo, N. Mascolo, A Menghini. "Antipyretic and antibacterial actions of Teucrium polium (L.)," Pharmacological research communications. vol. 16, 1984, pp. 21-29.

[26] Y. Lekbach, Z. Li, D. Xu, S. El Abed, Y. Dong, D. Liu, T. Gu, S.I. Koraichi, K. Yang, F. Wang. "Salvia officinalis extract mitigates the microbiologically influenced corrosion of 304L stainless steel by Pseudomonas aeruginosa biofilm," Bioelectrochemistry. vol. 128, 2019, pp. 193-203.

[27] M. Beheshti-Rouy, M. Azarsina, L. Rezaie-Soufi, M.Y. Alikhani, G. Roshanaie, S. Komaki. "The antibacterial effect of sage extract (Salvia officinalis) mouthwash against Streptococcus mutans in dental plaque: a randomized clinical trial," Iranian journal of microbiology. vol. 7, 2015, pp. 173.

[28] G. Bachir Raho, Z. Benattouche, A. Bevilacqua, M. Corbo, M. Sinigaglia, S. Pignatiello. "Antimicrobial Activity of Extracts from Salvia officinalis L on some Bacteria and Yeast," Journal of Biotechnology Research. vol. 2, 2016, pp. 31-35.

[29] M. Ghaedi, R. Naghiha, R. Jannesar, B. Mirtamizdoust. "Antibacterial and antifungal activity of flower extracts of Urtica dioica, Chamaemelum nobile and Salvia officinalis: Effects of $\mathrm{Zn}[\mathrm{OH}]$ 2 nanoparticles and Hp-2-minh on their property," Journal of Industrial and Engineering Chemistry. vol. 32, 2015, pp. 353-359.

[30] A.V. Pop, M. Tofană, S.A. Socaci, C. Pop, A.M. ROTAR, M. Nagy, L. SALANŢĂ. "Determination of Antioxidant Capacity and Antimicrobial Activity of Selected Salvia Species," Bulletin of University of Agricultural Sciences and Veterinary Medicine Cluj-Napoca Food Science and Technology. vol. 73, 2016, pp. 14-18.

[31] S. Škrovánková, L. Mišurcová, L. Machu. "3 antioxidant activity and protecting health effects of common medicinal plants," Advances in food and nutrition research. vol. 67, 2012, pp. 75.

[32] B.a.-E. Lixandru, N. Drăcea, C.C. Dragomirescu, E. Drăgulescu, I.L.a Coldea, L. Anton, E. Dobre, C. Rovinaru, I. Codiţă "Antimicrobial activity of plant essential oils against bacterial and fungal species involved in food poisoning and/or food decay," Roum Arch Microbiol Immunol. vol. 69, 2010, pp. 224-230.

[33] G.G. Nascimento, J. Locatelli, P.C. Freitas, G.L. Silva. “Antibacterial activity of plant extracts and phytochemicals on antibiotic-resistant bacteria," Brazilian journal of microbiology. vol. 31, 2000, pp. 247-256.

[34] E. Mosafa, S. Yahyaabadi, M. Doudi. "In-Vitro Antibacterial Properties of Sage (Salvia officinalis) Ethanol Extract against Multidrug Resistant Staphylococcus aureus, Escherichia coli, Pseudomonas aeruginosa and Klebsiella pneumoniae," Zahedan Journal of Research in Medical Sciences. vol. 16, 2014, pp. 42-46.

[35] D. Stanojevic, L. Comic, O. Stefanovic, S. Solujic-Sukdolak. "In vitro synergistic antibacterial activity of Salvia officinalis L. and some preservatives," Arch Biol Sci Belgrade. vol. 62, 2010, pp. $175-183$ 
[36] V. Pavić, M. Jakovljević, M. Molnar, S. Jokić. "Extraction of Carnosic Acid and Carnosol from Sage (Salvia officinalis L.) Leaves by Supercritical Fluid Extraction and Their Antioxidant and Antibacterial Activity," Plants. vol. 8, 2019, pp. 16.

[37] D.O. Ferrari, R.G. Lund, L. Zanella, W.A.R. Júnior, S.A.R. Junior. "Denture disinfection using Salvia officinalis L.: microbial load and selected properties of PMMA," Brazilian Journal of Oral Sciences. vol. 2019, pp. e18901-e18901.

[38] A. Ghorbani, M. Esmaeilizadeh. "Pharmacological properties of Salvia officinalis and its components," Journal of traditional and complementary medicine. vol. 7, 2017, pp. 433-440.

[39] N. Martins, L. Barros, C. Santos-Buelga, M. Henriques, S. Silva, I.C. Ferreira. "Evaluation of bioactive properties and phenolic compounds in different extracts prepared from Salvia officinalis L," Food chemistry. vol. 170, 2015, pp. 378-385.

[40] M. Fournomiti, A. Kimbaris, I. Mantzourani, S. Plessas, I. Theodoridou, V. Papaemmanouil, I. Kapsiotis, M. Panopoulou, E. Stavropoulou, E.E. Bezirtzoglou. "Antimicrobial activity of essential oils of cultivated oregano (Origanum vulgare), sage (Salvia officinalis), and thyme (Thymus vulgaris) against clinical isolates of Escherichia coli, Klebsiella oxytoca, and Klebsiella pneumoniae," Microbial ecology in health and disease. vol. 26, 2015 , pp. 23289.

[41] EMEA. COMMITTEE ON HERBAL MEDICINAL PRODUCTS (HMPC): ASSESSMENT REPORT ON SALVIA OFFICINALIS L., FOLIUM AND SALVIA OFFICINALIS L., AETHEROLEUM. In; 2010:39

[42] K. Horiuchi, S. Shiota, T. Hatano, T. Yoshida, T. Kuroda, T. Tsuchiya. "Antimicrobial activity of oleanolic acid from Salvia officinalis and related compounds on vancomycin-resistant enterococci (VRE)," Biological and Pharmaceutical Bulletin. vol. 30, 2007, pp. 1147-1149.

[43] A. Matkowski. "Plant in vitro culture for the production of antioxidants-a review," Biotechnology advances. vol. 26, 2008, pp. 548-560.

[44] S. Hassane, A. Farah, B. Satrani, M. Ghanmi, N. Chahmi, S. Soidrou, A. Chaouch. Chemical composition and antimicrobial activity of comorian Ocimum canum essential oil harvested in the region of Maweni Dimani-Grande Comoros. In, Chemistry for Sustainable Development: Springer; 2012:443-452

[45] A.K. Genena, H. Hense, A. Smânia Junior, S.M.d. Souza. "Rosemary (Rosmarinus officinalis): a study of the composition, antioxidant and antimicrobial activities of extracts obtained with supercritical carbon dioxide," Food Science and Technology (Campinas). vol. 28, 2008, pp. 463-469.

[46] A.K. Genena, H. Hense, A. Smânia Junior, S.M.d. Souza. "Rosemary (Rosmarinus officinalis): a study of the composition, antioxidant and antimicrobial activities of extracts obtained with supercritical carbon dioxide," Food Science and Technology. vol. 28, 2008, pp. $463-469$.

[47] T. Rozman, B. Jersek. "Antimicrobial activity of rosemary extracts (Rosmarinus officinalis L.) against different species of Listeria," Acta agriculturae Slovenica. vol. 93, 2009, pp. 51

[48] G. Kronvall. "Antimicrobial resistance at Karolinska hospital, Sweden: normalized resistance interpretation during a 30year follow-up on Staphylococcus aureus and Escherichia coli resistance development," Apmis. vol. 118, 2010, pp. 621-639.

[49] N. Jarrar, A. Abu-Hijleh, K. Adwan. "Antibacterial activity of Rosmarinus officinalis L. alone and in combination with cefuroxime against methicillin-resistant Staphylococcus aureus," Asian Pacific journal of tropical medicine. vol. 3, 2010, pp. 121-123.

[50] H. Abramovič, P. Terpinc, I. Generalić, D. Skroza, A. Klančnik, V. Katalinić, S. Smole Možina. "Antioxidant and antimicrobial activity of extracts obtained from rosemary (Rosmarinus officinalis) and vine (Vitis vinifera) leaves," Croatian journal of food science and technology. vol. 4, 2012, pp. 1-8.

[51] M. Kozlowska, A.E. Laudy, J. Przybyl, M. Ziarno, E. Majewska. "Chemical composition and antibacterial activity of some medicinal plants from Lamiaceae family," Acta Pol Pharm. vol. 72, 2015, pp. 757-767.

[52] J.R. de Oliveira, D. de Jesus, L.W. Figueira, F.E. de Oliveira, C. Pacheco Soares, S.E.A. Camargo, A.O.C. Jorge, L.D. de Oliveira. "Biological activities of Rosmarinus officinalis L.(rosemary) extract as analyzed in microorganisms and cells," Experimental Biology and Medicine. vol. 242, 2017, pp. 625-634.

[53] M.L. Atala, M.A.-G. Aldabagh. "Antibacterial activity of Rosmarinus officinalis and Dodonaea viscosa leaves extracts against
Escherichia coli and Staphylococcus aureus," Iraqi Journal of Science. vol. 58, 2017, pp. 1393-1397.

[54] G.P. Amaral, C.R. Mizdal, S.T. Stefanello, A.S.L. Mendez, R.L. Puntel, M.M.A. de Campos, F.A.A. Soares, R. Fachinetto. "Antibacterial and antioxidant effects of Rosmarinus officinalis L. extract and its fractions," Journal of traditional and complementary medicine. vol. 2018, pp.

[55] S. Moreno, T. Scheyer, C.S. Romano, A.A. Vojnov. "Antioxidant and antimicrobial activities of rosemary extracts linked to their polyphenol composition," Free Radical Research. vol. 40, 2006, pp. 223-231.

[56] G. Nieto, G. Ros, J. Castillo. "Antioxidant and antimicrobial properties of rosemary (Rosmarinus officinalis, L.): A Review," Medicines. vol. 5, 2018, pp. 98.

[57] J.D. Campo, M.-J. Amiot, C. Nguyen-The. "Antimicrobial effect of rosemary extracts," Journal of food protection. vol. 63, 2000, pp. $1359-1368$

[58] K. Karamanoli, D. Vokou, U. Menkissoglu, H.-I. Constantinidou. "Bacterial colonization of phyllosphere of Mediterranean aromatic plants," Journal of Chemical Ecology. vol. 26, 2000, pp. 2035-2048.

[59] A. Klančnik, B. Guzej, M.H. Kolar, H. Abramovič, S.S. MOŽINA. "In vitro antimicrobial and antioxidant activity of commercial rosemary extract formulations," Journal of food protection. vol. 72, 2009, pp. 1744-1752.

[60] S. Burt. "Essential oils: their antibacterial properties and potential applications in foods-a review," International Journal of Food Microbiology. vol. 94, 2004, pp. 223-253.

[61] B. Biswas, K. Rogers, F. McLaughlin, D. Daniels, A. Yadav. "Antimicrobial activities of leaf extracts of guava (Psidium guajava L.) on two gram-negative and gram-positive bacteria," International journal of microbiology. vol. 2013, 2013, pp.

[62] S. Puntawong, S. Okonogi, K. Pringproa. "In vitro antibacterial activity of Psidium guajava Linn. Leaf extracts against pathogenic bacteria in pigs," CMU J Nat Sci. vol. 2012, pp. 127-134.

[63] F.A. Gonçalves, M. Andrade Neto, J.N. Bezerra, A. Macrae, O.V.d. Sousa, A.A. Fonteles-Filho, R.H. Vieira. "Antibacterial activity of GUAVA, Psidium guajava Linnaeus, leaf extracts on diarrhea-causing enteric bacteria isolated from Seabob shrimp, Xiphopenaeus kroyeri (Heller)," Revista do Instituto de Medicina Tropical de Sao Paulo. vol. 50, 2008, pp. 11-15.

[64] M. Abdallah, I. Ahmed. "Comparative Study of Antibacterial and Phytochemical Screening of Ethanolic Extracts of Citrus aurentifolia and Psidium guajava on Some Clinical Isolates (Pseudomonas aeruginosa and Escherichia coli) of Patients Attending General Hospital Damagum, Yobe State, Nigeria," vol. 2018, pp.

[65] M.V. Silva, T.S. Frazão, M.M. Ferreira, J.S. Sales, D.B. Vieira, R.F. do Vale, L.H. do Carmo, T. Yano, P.M. Figueiredo. "Assessment in Vitro of Antibacterial Activity of Manipulated Product, on Solution Form, Obtained from Dry Extract of Leaves of Psidium guajava L,” International Journal of Chemistry. vol. 8, 2016, pp.

[66] E.A. Yaun, B.A. Vasquez. "Antibacterial activity of formulated Psidium guajava (guava) hand sanitizer gel on Staphylococcus aureus," University of the Visayas-Journal of Research. vol. 11, 2017, pp. $1-6$.

[67] K. Anas, P. Jayasree, T. Vijayakumar, P. Kumar. "In vitro antibacterial activity of Psidium guajava Linn. leaf extract on clinical isolates of multidrug resistant Staphylococcus aureus," vol. 2008, pp.

[68] A. Dhiman, A. Nanda, S. Ahmad, B. Narasimhan. "In vitro antimicrobial activity of methanolic leaf extract of Psidium guajava L," Journal of Pharmacy and Bioallied Sciences. vol. 3, 2011, pp. 226.

[69] N. Bhatnagar. "ANTIMICROBIAL ACTIVITY OF TRIGONELLA FOENUM GRAECUM EXTRACTS," Indian Journal of Environmental Sciences. vol. 21, 2017, pp. 45.

[70] R. Mishra, S. Mandloi, N. Yadav, J. Choithani. "PHYTOCHEMICAL ANALYSIS OF TRIGONELLA FOENUM GRAECUM AND ITS ANTIBACTERIAL ACTIVITY AGAINST STAPHYLOCOCCUS AUREUS," vol. 2016, pp.

[71] V. Sharma, P. Singh, A. Rani. "Antimicrobial activity of Trigonella foenum-graecum L.(Fenugreek)," European Journal of Experimental Biology. vol. 7, 2017, pp.

[72] S. Muzaffar, S.A. Rather, K.Z. Khan. "In vitro bactericidal and fungicidal activities of various extracts of saffron (Crocus sativus L.) stigmas from Jammu \& Kashmir, India," Cogent Food \& Agriculture. vol. 2, 2016, pp. 1158999.

[73] G. Okmen, S. Kardas, B. Bayrak, A. Arslan, H. Cakar. "The antibacterial activities of Crocus sativus against mastitis 
pathogens and its antioxidant activities," WJPPS. vol. 5, 2016, pp. 146-156.

[74] Z. Zulfa, C. Chia, Y. Rukayadi. "In vitro antimicrobial activity of Cymbopogon citratus (lemongrass) extracts against selected foodborne pathogens," International Food Research Journal. vol. 23, 2016, pp.

[75] J. Ewansiha, S. Garba, J. Mawak, O. Oyewole. “Antimicrobial Activity of Cymbopogon citratus (Lemon Grass) and It's Phytochemical Properties," vol. 2012, pp.

[76] A.J. Adegbegi, U. Usunobun, B.L. Adewumi. "Comparative studies on the chemical composition and antimicrobial activities of the ethanolic extracts of lemongrass leaves and stems. ," Asian Journal of Medical Sciences vol. 4, 2012, pp. 145-148.

[77] B.R. Singh, V. Singh, R.K. Singh, N. Ebibeni. "Antimicrobial activity of lemongrass (Cymbopogon citratus) oil against microbes of environmental, clinical and food origin," International Research Journal of Pharmacy and Pharmacology. vol. 1, 2011, pp. 228-236.

[78] M.M. Cowan. "Plant products as antimicrobial agents," Clinical microbiology reviews. vol. 12, 1999, pp. 564-582.

[79] S. Boutkhil, M. El Idrissi, A. Amechrouq, A. Chbicheb, S. Chakir, K. El Badaoui. "Chemical composition and antimicrobial activity of crude, aqueous, ethanol extracts and essential oils of Dysphania ambrosioides (L.) Mosyakin \& Clemants," Acta Botanica Gallica. vol. 156, 2009, pp. 201-209.

[80] R.S. Jesus, M. Piana, R.B. Freitas, T.F. Brum, C.F. Alves, B.V. Belke, N.J. Mossmann, R.C. Cruz, R.C. Santos, T.V. Dalmolin. "In vitro antimicrobial and antimycobacterial activity and HPLC-DAD screening of phenolics from Chenopodium ambrosioides L,' Brazilian journal of microbiology. vol. 49, 2018, pp. 296-302.

[81] M. Ajaib, T. Hussain, S. Farooq, M. Ashiq. "Analysis of antimicrobial and antioxidant activities of Chenopodium ambrosioides: an ethnomedicinal plant," Journal of Chemistry. vol. 2016, 2016, pp

[82] B. Ncube, J. Finnie, J. Van Staden. "Quality from the field: the impact of environmental factors as quality determinants in medicinal plants," South African journal of botany. vol. 82, 2012, pp. 11-20.

[83] R. Akula, G.A. Ravishankar. "Influence of abiotic stress signals on secondary metabolites in plants," Plant signaling \& behavior. vol. 6, 2011, pp. 1720-1731.

[84] A. Bouyahya, J. Abrini, A. El-Baabou, Y. Bakri, N. Dakka. "Determination of phenol content and antibacterial activity of five medicinal plants ethanolic extracts from North-West of Morocco," J Plant Pathol Microbiol. vol. 7, 2016, pp. 2.

[85] J. Wan, A. Wilcock, M. Coventry. "The effect of essential oils of basil on the growth of Aeromonas hydrophila and Pseudomonas fluorescens," Journal of Applied Microbiology. vol. 84, 1998, pp. 152-158.

[86] J. El Amri, K. Elbadaoui, T. Zair, H. Bouharb, S. Chakir, T. Alaoui. "Étude de l'activité antibactérienne des huiles essentielles de Teucrium capitatium L et l'extrait de Siléne vulgaris sur différentes souches testées," Journal of Applied Biosciences. vol. 82, 2014, pp. 7481-7492.

[87] H. NIKAIDO. "Multidrug Efflux Pumps of Gram-Negative Bacteria," Journal of bacteriology. vol. 178, 1996, pp. 5853-5859.

[88] C.A. Semeniuc, C.R. Pop, A.M. Rotar. "Antibacterial activity and interactions of plant essential oil combinations against Gram-positive and Gram-negative bacteria," journal of food and drug analysis. vol. 25, 2017, pp. 403-408

[89] B. Poorabbas, J. Mardaneh, Z. Rezaei, M. Kalani, G. Pouladfar, M.H. Alami, J. Soltani, A. Shamsi-Zadeh, S. Abdoli-Oskooi, M.J. Saffar. "Nosocomial Infections: Multicenter surveillance of antimicrobial resistance profile of Staphylococcus aureus and Gram negative rods isolated from blood and other sterile body fluids in Iran," Iranian journal of microbiology. vol. 7, 2015, pp. 127.

[90] S. Vasoo, J.N. Barreto, P.K. Tosh. Emerging issues in gram-negative bacterial resistance: an update for the practicing clinician. In, Mayo Clinic Proceedings: Elsevier; 2015:395-403

[91] R. Valsaraj, P. Pushpangadan, U.W. Smitt, A. Adsersen, U. Nyman. "Antimicrobial screening of selected medicinal plants from India," Journal of Ethnopharmacology. vol. 58, 1997, pp. 75-83.

[92] I.C. Zampini, S. Cuello, M.R. Alberto. "Antimicrobial activity of selected plant species from 'the Argentine Puna' against sensitive and multi-resistant bacteria," Journal of Ethnopharmacology. vol. 124, 2009, pp. 499-505.

[93] I.L. Elisha, F.S. Botha, L.J. McGaw, J.N. Eloff. "The antibacterial activity of extracts of nine plant species with good activity against
Escherichia coli against five other bacteria and cytotoxicity of extracts," BMC complementary and alternative medicine. vol. 17, 2017, pp. 133.

[94] T.J. Makhafola, B.B. Samuel, E.E. Elgorashi, J.N. Eloff. “Ochnaflavone and ochnaflavone 7-O-methyl ether two antibacteria Biflavonoids from Ochna pretoriensis (ochnaceae)," Natural product communications. vol. 7, 2012, pp $1934578 X 1200701216$

[95] M. Vaara. "Agents that increase the permeability of the outer membrane," Microbiology and Molecular Biology Reviews. vol. 56, 1992, pp. 395-411.

[96] X.-Z. Li, H. Nikaido. "Efflux-mediated drug resistance in bacteria: an update," Drugs. vol. 69, 2009, pp. 1555-1623.

[97] H. Chandra, P. Bishnoi, A. Yadav, B. Patni, A. Mishra, A. Nautiyal. "Antimicrobial resistance and the alternative resources with special emphasis on plant-based antimicrobials - a review," Plants. vol. 6, 2017, pp. 16

[98] S. Inouye, H. Yamaguchi, T. Takizawa. "Screening of the antibacterial effects of a variety of essential oils on respiratory tract pathogens, using a modified dilution assay method," Journal of Infection and Chemotherapy. vol. 7, 2001, pp. 251-254.

Youssef LAHLOU, PhD student at Chouaïb Doukkali University.Faculty of Sciences El Jadida. Topics of research:

Bioactive Molecules. Screening of chemical and biological activities of Moroccan medicinal plants (antioxidant, anticancer, antibacterial, antifungal activity...), fractionation and purification of the bio active compounds .

Belkassem El AMRAOUI, Professor at Faculty Polydisciplinary of Taroudant, Ibn Zohr University, Agadir and Researcher Professor in the Biotechnology, Materials and Environment Laboratory research team (Faculty Polydisciplinary of Taroudant) and Control Quality in Bio-control Industry \& Bioactive Molecules research team (Faculty of Sciences El Jadida).Topics of research: -Extraction, study and purification of biomolecules from marine sponges on the Moroccan coast.-Activity of Haliscosamine against Fusarium oxysporum f.sp. melonis: In vitro and in vivo analysis.-In vitro screening of antifungal activity of marine sponge extracts against phytopathogenic fungi.

Toufiq BAMHAOUD, Professor at Chouaïb Doukkali University. Faculty of Sciences El Jadida since 1993, and Researcher Professor in the Control Quality in Bio-control Industry \& Bioactive Molecules research team. Research work :- Cobalt-Catalyzed Radical Oxygenation with Molecular Oxygen. -ChemInform Abstract: 1,2,5-ortho Esters of D-Arabinose as Versatile Arabinofuranosidic Building Blocks. Concise Synthesis of the Tetrasaccharidic Cap of the Lipoarabinomannan of Mycobacterium tuberculosis. - Seasonal and geographical variation range of antifungal activity of sponge extracts from the Moroccan Atlantic coasts. 